\begin{tabular}{|l|l|l||}
\hline \multicolumn{2}{|c|}{ PublisherInfo } \\
\hline \hline PublisherName & $:$ & BioMed Central \\
\hline \hline PublisherLocation & $:$ & London \\
\hline \hline PublisherImprintName & $:$ & BioMed Central \\
\hline \hline
\end{tabular}

\title{
Ventilator-associated lung injury in ARDS
}

\begin{tabular}{|l|l|l||}
\hline \multicolumn{2}{|c|}{ ArticleInfo } \\
\hline \hline ArticleID & $:$ & 4186 \\
\hline \hline ArticleDOI & $:$ & $10.1186 /$ ccf-2000-4129 \\
\hline \hline ArticleCitationID & $:$ & 4129 \\
\hline \hline ArticleSequenceNumber & $:$ & 45 \\
\hline \hline ArticleCategory & $:$ & Paper Report \\
\hline ArticleFirstPage & $:$ & 1 \\
\hline \hline ArticleLastPage & $:$ & 2 \\
\hline \hline & & RegistrationDate : 2000-1-17 \\
\hline ArticleHistory & $:$ & OnlineDate \\
\hline \hline ArticleCopyright & $:$ & Current Science Ltd2000-1-17 \\
\hline \hline ArticleGrants & $:$ & \\
\hline \hline ArticleContext & $:$ & 1305422 \\
\hline \hline
\end{tabular}




\section{Keywords}

ALI, ARDS, lung injury, ventilator

\section{Comments}

An excellent review which presents literature from both animal experiments and human clinical trials in an attempt to form a consensus view on ventilator-induced lung injury (VILI). Animal data pertaining to alveolar overdistension, as a result of increased transpulmonary pressure during mechanical ventilation, is examined, and the difficulties in translating this evidence into the human arena are discussed. The authors highlight the fact that we can only infer that VILI occurs in humans, since a study to prove this can not be performed for obvious reasons. Nevertheless, clinical observations show that protective ventilator strategies can influence morbidity and mortality and the much publicised multicentre trial, recently completed by the NIH, is quoted here. Risk factors, incidence, monitoring, morbidity, mortality and prevention of VILI are all covered by this consensus conference. The conclusions reached, are that low tidal volumes, PEEP titrated to the PV curve, and possibly prone positioning may all protect against VILI.

\section{Additional information}

\section{References}

1. International consensus conference in intensive care medicine: Ventilator-associated lung injury in ARDS. Intensive Care Med. 1999, 25: 1444-1452.

This PDF file was created after publication. 